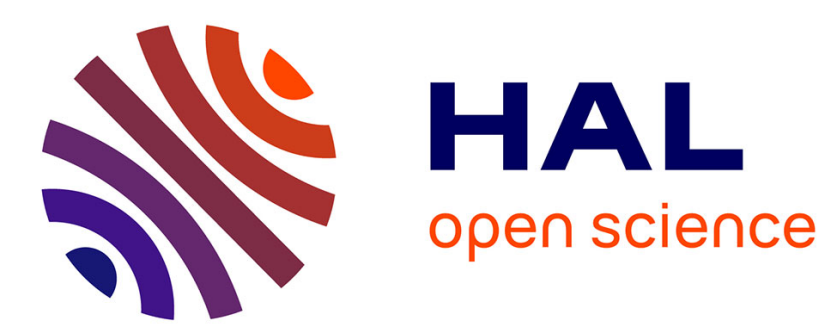

\title{
Mechanical behaviour of black anodic films on 7175 aluminium alloy for space applications
}

Yann Goueffon, Catherine Mabru, Michel Labarrère, Laurent Arurault, Claire Tonon, Pascale Guigue

\section{- To cite this version:}

Yann Goueffon, Catherine Mabru, Michel Labarrère, Laurent Arurault, Claire Tonon, et al.. Mechanical behaviour of black anodic films on 7175 aluminium alloy for space applications. Metal Finishing, 2010, 108 (2), pp.22-27. 10.1016/S0026-0576(10)80037-6 . hal-01852209

\section{HAL Id: hal-01852209 \\ https://hal.science/hal-01852209}

Submitted on 1 Aug 2018

HAL is a multi-disciplinary open access archive for the deposit and dissemination of scientific research documents, whether they are published or not. The documents may come from teaching and research institutions in France or abroad, or from public or private research centers.
L'archive ouverte pluridisciplinaire HAL, est destinée au dépôt et à la diffusion de documents scientifiques de niveau recherche, publiés ou non, émanant des établissements d'enseignement et de recherche français ou étrangers, des laboratoires publics ou privés. 


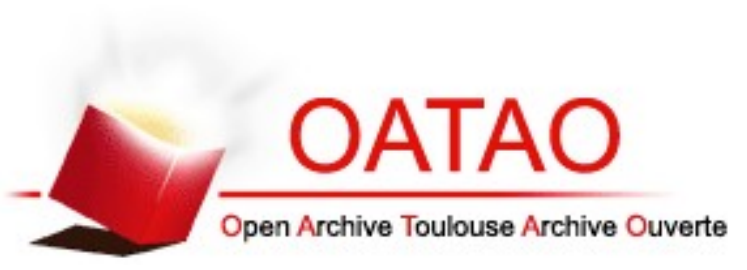

\section{Open Archive Toulouse Archive Ouverte (OATAO)}

OATAO is an open access repository that collects the work of Toulouse researchers and makes it freely available over the web where possible.

This is a publisher-deposited version published in: http://oatao.univ-toulouse.fr/ Eprints ID: 4371

To link to this article: DOI: 10.1016/S0026-0576(10)80037-6

URL: http://dx.doi.org/10.1016/S0026-0576(10)80037-6

To cite this version: GOUEFFON Yann, MABRU Catherine, LABARRERE Michel, ARURAULT Laurent, TONON Claire, GUIGUE Pascale. Mechanical behaviour of black anodic films on 7175 aluminium alloy for space applications. Metal Finishing, 2010, vol. $108, n^{\circ} 2$, pp. 22-27.

ISSN 0026-0576

Any correspondence concerning this service should be sent to the repository administrator: 
BY YANN GOUEFFON ${ }^{4},{ }^{\circ}$, CATHERINE MABRU $^{B}$, MICHEL LABARRÈRE $^{B}$, LAURENT ARURAULT $^{c}$, CLAIRE TONON ${ }^{D}$, PASCALE GUIGUEA

\section{A. CNES, 18 AVENUE EDOUARD BELIN, 31401 TOULOUSE CEDEX 9, FRANCE \\ B. UNIVERSITÉ DE TOULOUSE, ISAE, DÉPARTEMENT MÉCANIQUE DES STRUCTURES ET MATÉRIAUX, 10 AVENUE EDOUARD BELIN BP54032, 31055 TOULOUSE CEDEX 4, FRANCE \\ C. UNIVERSITÉ DE TOULOUSE, CIRIMAT-LCMIE, INSTITUT CARNOT, UNIVERSITÉ PAUL SABATIER, 118 ROUTE DE \\ D. EADS ASTRIUM SATELLITES, 31 AVENUE DES COSMONAUTES, 31402 TOULOUSE CEDEX 4, FRANCE}

\section{Mechanical Behavior of Black Anodic Films on 7175 Aluminium Alloy for Space Applications}

(Editor's note: This article originally appeared in Surface o Coatings Technology 204 (2009) 1013-1017, and is reprinted berein with permission. (C) 2009 Elsevier B.V. All rights reserved.)

B lack anodic films on aluminium alloys have been used in space industry for many years. Such treatments provide specific characteristics to surfaces (solar absorptance $\alpha_{s}>0.93$ and normal emittance $\varepsilon_{n}>0.90$ ) managing passive thermal regulation. The process used to obtain these black films is based on porous anodizing. This is not a deposit of a coating but an electrochemical oxidation of the surface of the aluminium alloy. Therefore, the adhesion of anodic film on its substrate has always been considered very strong. Before the launch, parts of satellites are submitted to thermal cycles under vacuum to simulate the space environment. Cases of flaking of black anodic films have been observed after those tests when pulling-off tapes used to fix thermocouples [1].

In this context, the aim of this paper is to better understand mechanisms leading to flaking. In order to precisely assess the mechanical behavior of the film, depending on its initial porosity, residual stresses were first measured after each step of the process. The coefficient of thermal expansion was then evaluated by beam bending analysis to determine the thermal stresses occurring during processing and aging. Next, the tensile strength was evaluated via four-point bending tests. Finally, the evolution of adhesion during aging (thermal cycling) was followed by scratch tests. A finite element model was developed to simulate the combined effects of thermal stresses and film cracking on the stress field at the interface film/substrate.

\section{EXPERIMENTAL PROCEDURE}

2.1. Material. The substrate material was the $7175 T 7351$ aluminium alloy, often used in space industry. Its chemical composition in weight percent is: $1.62 \% \mathrm{Cu}, 0.12 \% \mathrm{Fe}$, $2.42 \% \mathrm{Mg}, 0.01 \% \mathrm{Mn}, 0.06 \% \mathrm{Si}, 5.75 \% \mathrm{Zn}, 0.041 \% \mathrm{Ti}, 0.21 \%$ $\mathrm{Cr}$ and $\mathrm{Al}$ account for the remainder. Its Young modulus is $E s=72 \mathrm{GPa}$, its Poisson coefficient is $. s=0.33$ and its coefficient of thermal expansion is as $=2.34 \times 10^{-5} \mathrm{~K}^{-1}$.

2.2. Black anodizing process. The process of black anodizing followed the ESA Standard [2] for spacecraft design involving four consecutive steps: surface pretreatments, anodizing, coloring and sealing. Samples were rinsed with distilled water after each step.

The alloy sheet $(3 \times 20 \times 40 \mathrm{~mm}$ or $10 \times 20 \times 160 \mathrm{~mm})$ was degreased with ethanol and erched in $\mathrm{Na}_{2} \mathrm{CO}_{3}(6.2$ $\mathrm{g} / \mathrm{L})$ and $\mathrm{Na}_{3} \mathrm{PO}_{4}(12.5 \mathrm{~g} / \mathrm{L})$ aqueous mixed solution for 5 min at $93^{\circ} \mathrm{C}$ and neutralized in aqueous $\mathrm{HNO}_{3}$ $(50 \% \mathrm{v} / \mathrm{v})$ for $3 \mathrm{~min}$. at room temperature.

The aluminium sheet was used as anode and a lead plate as counter-electrode in the electrochemical cell. The anodizing was run for $60 \mathrm{~min}$. in the galvanostatic mode $\left(\mathrm{Ja}=1.2 \pm 0.1 \mathrm{~A} / \mathrm{dm}^{2}\right)$ using a sulfuric acid solution $(150 \mathrm{~g} / \mathrm{L})$ thermally regulated. Changing the anodizing temperature between $5^{\circ} \mathrm{C}$ and $25^{\circ} \mathrm{C}$ allow controlling the initial porosity (i.e. before coloring and sealing) (Fig. 1) [3-5]. Porosity was quantified by image analysis after observations with a field-emission gun scanning electron microscope (FEG-SEM JEOL JSM6700F device). The film thickness is around $20 \mu \mathrm{m}$ to insert enough black dyes during the coloring.

The anodized part was colored by immersion in two successive baths: first for $15 \mathrm{~min}$. in a solution of cobalt acerate $(200 \mathrm{~g} / \mathrm{L})$ regulated at $43 \pm 2^{\circ} \mathrm{C}$, and then for 10

Corresponding author. CNES, DCT/AQ/MP, 18 Avenue Edouard Belin, 31401 Toulouse

Cedex 9, France. Tel.: +33 561339 150; fax: +33 561339095

E-mail address: Yann.Goueffon@isae.fr (Y. Goueffon). 


\section{TECHNICALIYspeaking}

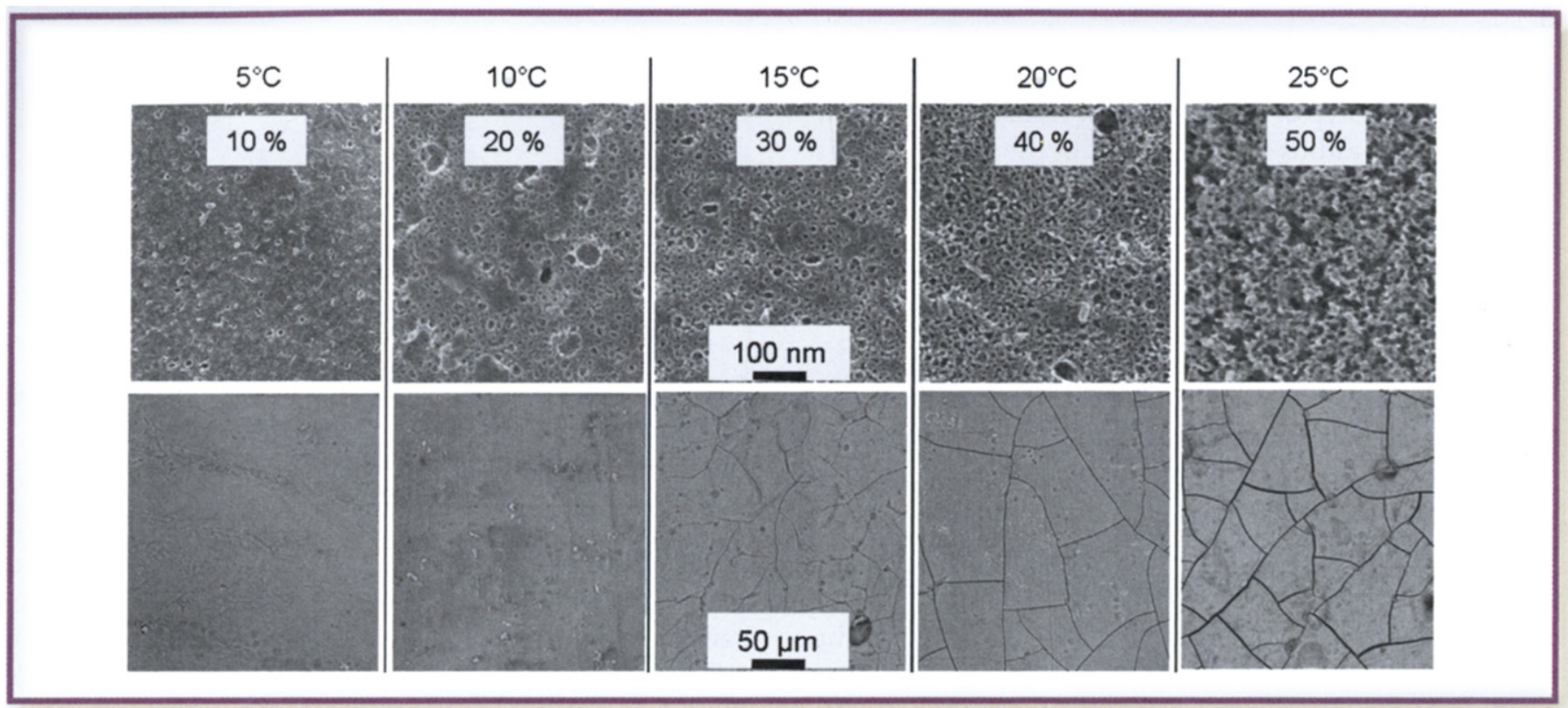

Fig. 1. FEG-SEM surface views of anodic films with different anodizing temperatures before and after coloring and sealing at nano and meso scales.

min. in ammonium hydro-sulphide $(30 \mathrm{~g} / \mathrm{L})$ at room temperature.

The sealing step occurred for $25 \mathrm{~min}$ in a bath at $98 \pm 2^{\circ} \mathrm{C}$ made up of nickel acetate $\left(\mathrm{NiCH}_{3} \mathrm{COO}, 4 \mathrm{H}_{2} \mathrm{O}\right)$ and boric acid ( $5 \mathrm{~g} / \mathrm{L}$ both).

\subsection{Residual stresses measurements in the film. Residual} stresses in the film were measured by beam bending analysis. Thin substrates $(200 \mu \mathrm{m})$ were prepared by a grinding on $\mathrm{SiC}$ paper (240-1200 grits) and polishing with diamond pastes from $6 \mu \mathrm{m}$ to $1 / 4 \mu \mathrm{m}$; they were anodized on one side $(20 \mathrm{~mm} \times 20 \mathrm{~mm})$. The curvatures of the samples induced by stresses were measured ex-situ on $17.5 \mathrm{~mm}$ with a Mahr Perthometer Concept with a sensor MFW250.

\subsection{Coefficient of thermal expansion (CTE) determination.}

To evaluate the CTE of the film, curvature measurements were realized at different temperatures. Samples were warmed up to $130^{\circ} \mathrm{C}$ with a heating stage and the film temperature was controlled with a thermocouple. Curvature measurements were performed during cooling $\left(1^{\circ} \mathrm{C} / \mathrm{min}\right)$.

\subsection{Film tensile strength measurements. The samples}

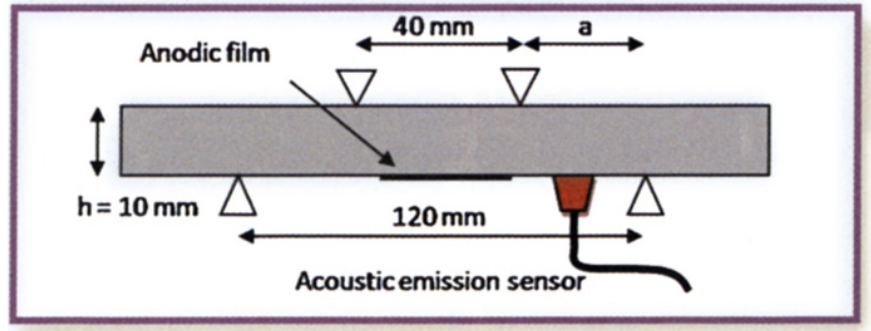

Fig. 2 .Schematic of the four-point bending test.
$(160 \times 20 \times 10 \mathrm{~mm})$ were anodized on a limited area. The tensile strength was determined with four-point bending tests performed on a tensile testing device (Adamel DY26) (Fig. 2). Acoustic emission measurements were used to determine the cracking load of the film $(\mathrm{Lc})$. Post-experiment SEM observations were performed to detect the presence of cracks in the film.

2.6. Adhesion measurements. Adhesion measurements were evaluated using a scratch-test device (CSM Revetest instrument) with a diamond stylus (Rockwell, $200 \mu \mathrm{m}$ radius tip). Scratch tests were configured with an increasing normal load (loading speed: $30 \mathrm{~N} / \mathrm{min}$; advance speed: $5 \mathrm{~mm} / \mathrm{min}$ ). The resulting scratch-print of $5 \mathrm{~mm}$ length was observed by SEM to determine the corresponding normal load. Given values are averages of six different scratches on each sample.

\subsection{Numerical simulation. A finite element simulation} was used to evaluate mechanical behavior of a thin film on its substrate. SAMCEF was used to perform isotropic thermo-elastic calculations with 2-dimensional plane strain hypotheses. The geometry used was a substrate (thickness of $3 \mathrm{~mm}$ ) with an anodic film of $20 \mu \mathrm{m}$. A straight crack perpendicular to the surface of 1 micron width and a variable length was added through the film. Mesh size has been validated by comparing $\mathrm{KI}$ with theoretical values. Cases of crazing were sometimes observed just after the sealing step. Thus, the impact of the presence of a crack through the coating on the interfacial stresses has been observed when thermally loaded. For a preliminary analysis the interfacial stress is defined as the difference between stresses (direction parallel to the surface) in the coating and in the substrate near the interface. 


\section{TECHNICALY Ypeaking}

\section{RESULTS AND DISCUSSION}

3.1. Residual stresses. Residual stresses have been measured after each step of the process for films with different porosities. The radius of curvature $\mathrm{R}$ of the thin sample is linked with stresses in the film by relation (1) [6]. Stresses are considered to be uniform in the film:

$\sigma_{\text {Film }}=\frac{E_{f} e_{i}}{6 R\left(1-\nu_{i}\right)} \frac{1+4 \alpha \beta+6 \alpha^{2} \beta+4 \alpha^{3} \beta+\alpha^{4} \beta^{2}}{(1+\alpha)(1+\alpha \beta)}$

with $\quad \alpha=\frac{e_{\mathrm{s}}}{e_{\mathrm{f}}}$ and $\beta=\frac{E_{\mathrm{s}}\left(1-v_{\mathrm{r}}\right)}{E_{\mathrm{f}}\left(1-v_{\mathrm{s}}\right)} e_{\mathrm{s}}$ and $e_{\mathrm{f}} \quad$ are the thicknesses of the substrate and the film respectively. Poisson coefficient of the film, .f, was assumed to be 0.28 [7]. The Young modulus of the film, $E_{f}$ was measured by nanoindentation as a function of the porosity and will be the aim of a forthcoming paper [8]. To sum up, the modulus decreased from $80 \mathrm{GPa}$ to $20 \mathrm{GPa}$ for films with porosities increasing from $10 \%$ to $50 \%$. The results are reported in Fig. 3, the percentages represent initial porosities.

After the anodizing step, residual stresses are compressive in the film, mainly due to the difference of molar volume between films and substrates $[9,10]$. Alwitt et al. [11,12] found tensile stresses (around 15 $\mathrm{MPa}$ ) after anodizing of 5657 aluminium alloy. They have shown that residual stresses are independent from the film's thickness but are depending on the substrate (5XXX and 6XXX series). The reason for this dependence is not yet well known. Nevertheless, alloying elements, especially copper [13], modify the growth mechanism of the films. The copper content in the AA7175 being about $1.2 \%$, the change of residual stresses could be explained by modification of the film morphology.

After insertion of dyes in the porosity, residual stresses are tensile and increase with initial porosity (i.e. with the quantity of introduced dyes).

The sealing step performed in boiling water (with addition of nickel acetate) is usually considered as a hydration

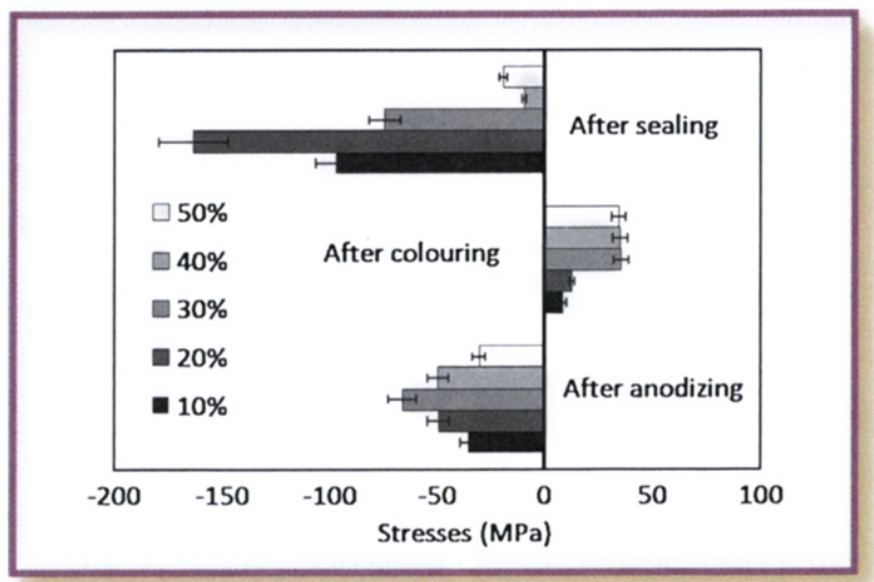

Fig. 3 Residual stresses measured after each step of the process (anodizing, coloring, sealing) for anodic films with differentinitial porosities.

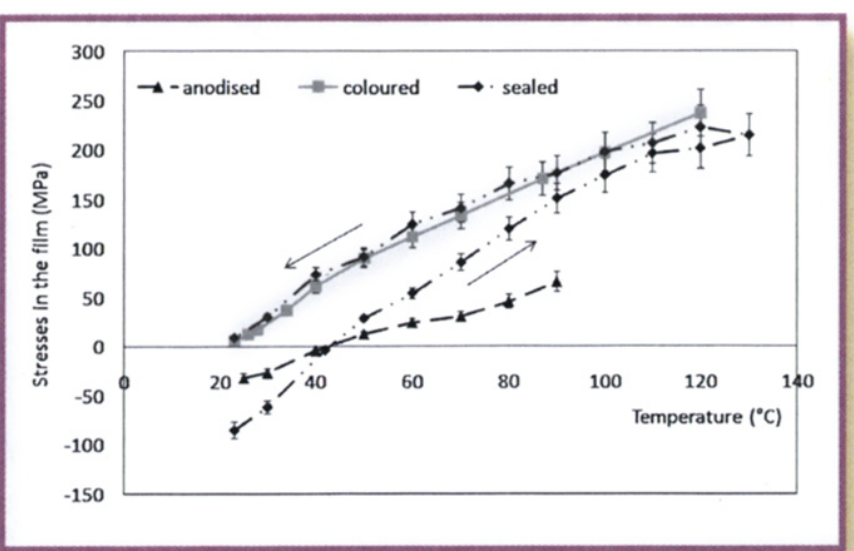

Fig. 4. Stress in a film with an initial porosity of $10 \%$ as a function of the temperature just after anodizing, after coloring, and after sealing.

of alumina, inducing a volume expansion of the film and thus large compressive residual stresses. Alwitt et al. [11] have shown that the compressive stress increases with the sealing time confirming the relation between compressive stresses and the quantity of hydrated alumina.

For initial porosities higher than $30 \%$, stresses are negligible. Actually, residual stresses were released by the presence of cracks through the films with high porosities (Fig. 1).

3.2. Causes of crazing. 3.2.1. Coefficient of thermal expansion (CTE) Relation (1) was used to calculate the stresses in the film at different temperatures. The experimental relation between stresses and temperature was established and assumed to be linear in the range of $20-70{ }^{\circ} \mathrm{C}$ (stable water content, homogeneous temperature).

The CTE of the film was deduced from relation (2) that gives the stresses in a coating due to a variation of temperature:

$\Delta \sigma=\frac{E_{\mathrm{f}}}{\left(1-v_{\mathrm{f}}^{2}\right)}\left[\alpha_{\mathrm{s}}\left(1+v_{\mathrm{s}}\right]-\alpha_{\mathrm{f}}\left(1+v_{\mathrm{f}}\right)\right] \Delta \theta$

with $\theta$ the temperature and $\alpha_{\mathrm{f}}$ the CTE of the film. Stresses are here considered homogenous in the film.

As an example, Fig. 4 represents stresses in a film versus the temperature. Same results were obtained whatever the porosity. The CTE of uncolored and unsealed films was found to be nearly five times lower $\left(5 \times 10^{-6} \mathrm{~K}^{-1}\right)$ than the aluminium's one confirming previous works of Alwitt et al. [11] who found the same ratio. In addition, stresses measured once back at ambient temperature are equivalent to residual stresses before heating.

After coloring, the CTE of anodic films is nearly 10 times lower than the substrate's one. No modification of residual stresses (at $20^{\circ} \mathrm{C}$ ) was induced by the test.

During heating and cooling of colored and sealed films, the slope is comparable with the sample colored but not sealed proving that the CTE is not modified by hydration. However, compressive residual stresses are released during the test because dehydration may occur at a tempera- 


\section{TECHNICALLYspeaking}

ture over $100^{\circ} \mathrm{C}[14]$.

The large difference between CTE of the substrate and the film is leading to tensile stresses in the film during sealing at $100^{\circ} \mathrm{C}$. This loading may explain cases of crazing. Nevertheless, the CTE was not significantly varying with the initial porosity.

3.2.2. Tensile strength. All the coated area was submitted to a uniform deformation at the rupture of the film during bending:

$\varepsilon_{\mathrm{R}}=\frac{L_{\mathrm{C}} \mathrm{ah}}{4 I_{\mathrm{S}} E_{S}}$

$a$ and $b$ are defined on Fig. $1 ; I_{S}$ is the quadratic moment of the sample.

The film was considered purely elastic and its limit tensile stress $\left(\sigma_{\mathrm{R}}\right)$ is:

$\sigma_{\mathrm{R}}=E_{\mathrm{f}} \varepsilon_{\mathrm{R}}+\sigma_{\text {residual }}$

Each given value is the average of three different tests.

With increasing porosity, the tensile strength of the anodic film was expected to decrease as described by Ryshkewitch-Duckworth [15]. In addition, a collapse of the tensile strength of ceramics for porosities between 30 and $50 \%$ has been shown by Knudsen et al. [16] corresponding to the transition from isolated to interconnected porosity.

Nevertheless, Fig. 5 shows that the tensile strength of uncolored and unsealed films increases for porosities from $10 \%$ to $30 \%$, while the strength decreases at higher porosities. The porosity was controlled by changing the anodizing temperature that may change the composition of the anodic film and may explain the increase of limit tensile stress. For porosities higher than $30 \%$, the effects of the porosity become preponderant and the tensile strength decreases.

The limit tensile stress is decreased by the coloring step. The quantity of dyes included in the film increases with

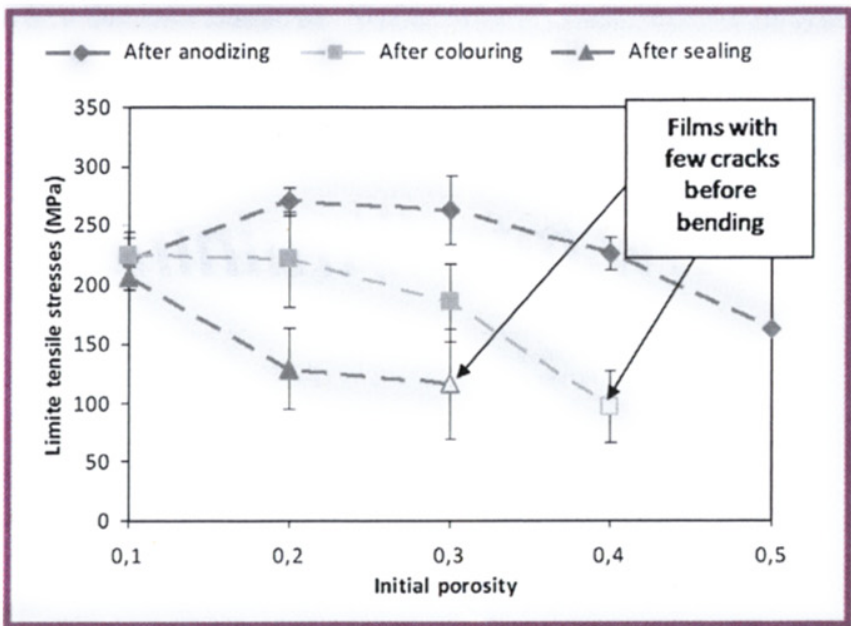

Fig. 5. Tensile strength of the anodic film at each step of the process and depending on the initial porosity. the porosity, that explains the more important loss of

$\mathrm{Co}\left(\mathrm{CH}_{3} \mathrm{COO}\right)_{2}+\left(\mathrm{NH}_{4}\right)_{2} \mathrm{~S} \rightarrow \mathrm{CoS}+2 \mathrm{CH}_{3} \mathrm{COONH}_{4}$

tensile strength for high porosities. The reaction of precipitation occurring inside pores during dying is [17]:

However, an additional chemical reaction between acetates and the film could explain this weakening. Further tests such as coloring with cobalt nitrates could

$\mathrm{Al}_{2} \mathrm{O}_{3}+(n+1) \mathrm{H}_{2} \mathrm{O} \rightarrow 2 \mathrm{AlOOH}+n \mathrm{H}_{2} \mathrm{O}(n>1)$

allow assessing this point.

The hydration of the film enhances this tendency. The transformation occurring during sealing is:

The resulting hydrated aluminium oxi-hydroxide often looks like a gel having a negligible mechanical resistance. For porosities of $40 \%$ and $50 \%$, the film was crazed after the sealing step at $100^{\circ} \mathrm{C}$ and, therefore, measurements are not comparable.

Considering the previous results, at the beginning of the sealing at $99^{\circ} \mathrm{C}$, films with $40 \%$ porosity are under tensile thermal stresses of approximately $100 \mathrm{MPa}$. Added with the tensile residual stresses after coloring ( $35 \mathrm{MPa}$ ), the global stresses in the film are higher than its limit tensile stress $(100 \mathrm{MPa})$.

Thus, the differential thermal dilatations associated with a very low limit tensile stress of highly porous anodic films explains the crazing phenomenon.

3.3. Aging and flaking. The evolution of the adhesion of the two crazed samples was observed after aging. Thermal cycling between $-80^{\circ} \mathrm{C}$ and $+80^{\circ} \mathrm{C}$ (dwells of $10 \mathrm{~min}$., warming/cooling speed of $10^{\circ} \mathrm{C} / \mathrm{min}$ ) were performed under dried nitrogenous atmosphere. Self-flaking of particles was observed after ageing on samples with $50 \%$ porosity.

Scratch-testing was used to compare evolutions of the

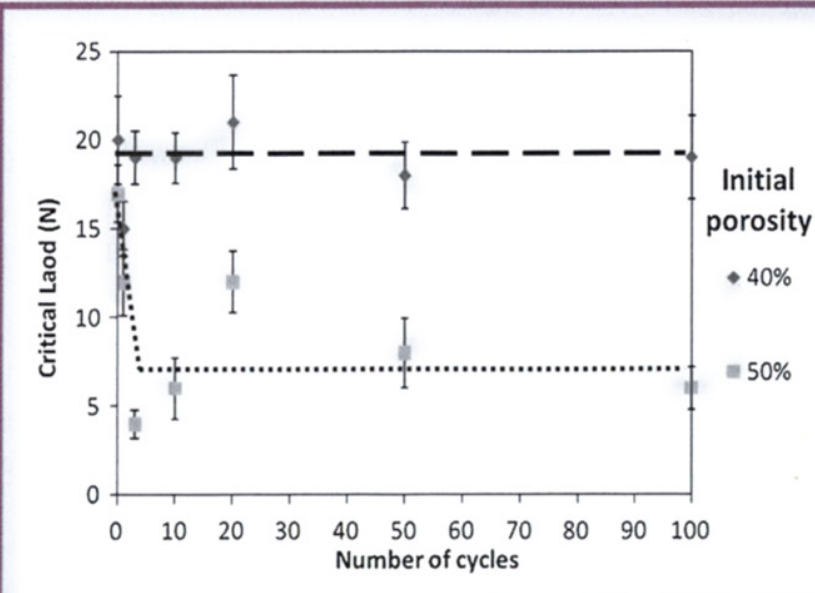

Fig. 6. Evolution of the scratch test critical load with the number of thermal cycles for samples of $40 \%$ and $50 \%$ of initial porosites. 


\section{TECHNICALLYspeaking}

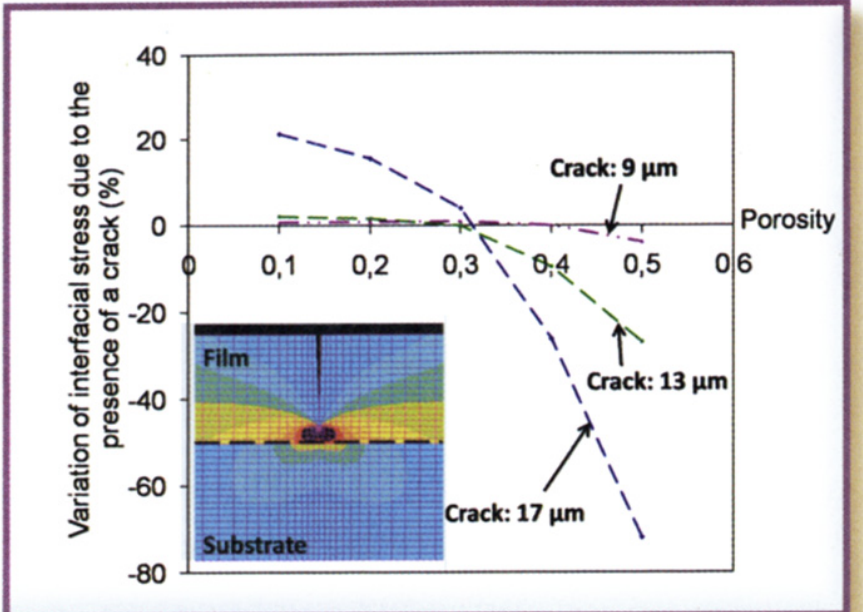

Fig. 7. Variations of the interfacial stress in the direction of the interface due to the presence of a crack through the porous film at $80^{\circ} \mathrm{C}$.

Scratch-testing was used to compare evolutions of the critical load defined as the lower load provoking a lateral flaking along the scratch [18]. The critical load is constant for black anodic films with an initial porosity of $40 \%$ whatever the number of cycles performed (Fig. 6). Thermal cycles between $-80^{\circ} \mathrm{C}$ and $+80^{\circ} \mathrm{C}$ have no impact on the measured adhesion. On the contrary, a loss of adhesion occurred after the first thermal cycle for samples with an initial porosity of $50 \%$.

The difference of CTE between the film and the substrate results in tensile thermal stresses in the film at temperatures higher than $20^{\circ} \mathrm{C}$. In addition, the water loss of the sample during ageing would result in tensile stresses in the film. Cracks in samples with $50 \%$ of initial porosity may propagate under thermal loading resulting in the loss of adhesion observed.

3.4. Numerical simulation. Thermo-mechanical properties of colored and sealed films were used. A thermal load of $+80^{\circ} \mathrm{C}$ was applied. The influence of the presence of a crack in the film on the variations of interfacial stresses

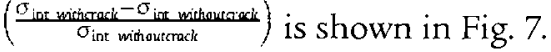

Two different behaviors depending on the porosity (i.e. elasticity) of the film are observed. For porosities lower than $30 \%$, the presence of a short crack $(<13 \mu \mathrm{m})$ has no impact on the interfacial stress considered. When cracks become longer $(17 \mu \mathrm{m})$, the interfacial stress increases. If cracks are long enough, tensile stresses in front of the crack are transmitted by the rigidity of the film until the interface. Interfacial stresses are enhanced.

For films showing porosity higher than $40 \%$, the presence of cracks causes a high deformation of the film with a low increase of stresses (high elasticity). Tensile stresses are in majority transmitted to the more rigid substrate. Interfacial stresses are released.

The width of cracks has always been found to increase during aging. This suggests that heating during thermal cycling propagates cracks through the film. However, it seems to have a limired impact on the interfacial stresses
A uniquely global publication focusing on on peening, blasting, cleaning and vibratory finishing! Also offering training courses!

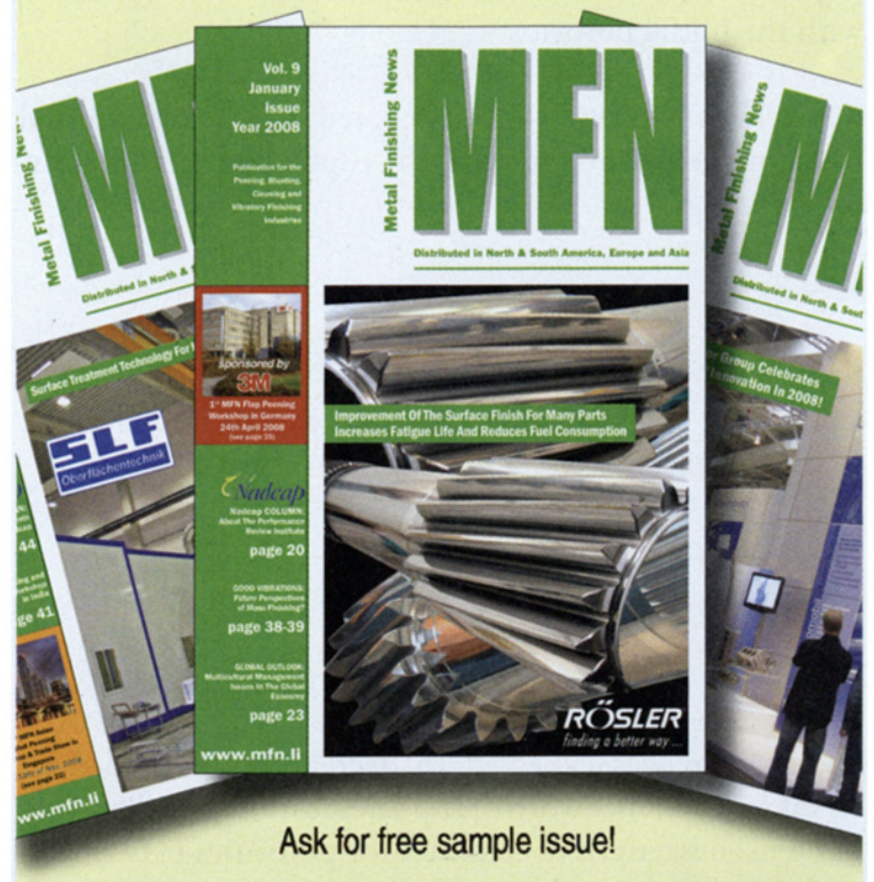

MFN (Metal Finishing News) is distributed in 67 countries and published 6 times a year. www.mfn.li

MFN offers training courses for: shot peening, flap peening and mass finishing

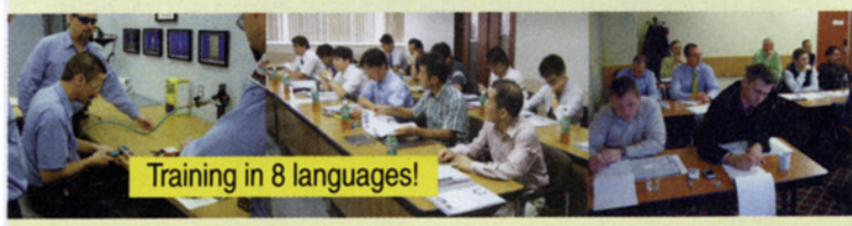

\section{www.mfn.li/training}

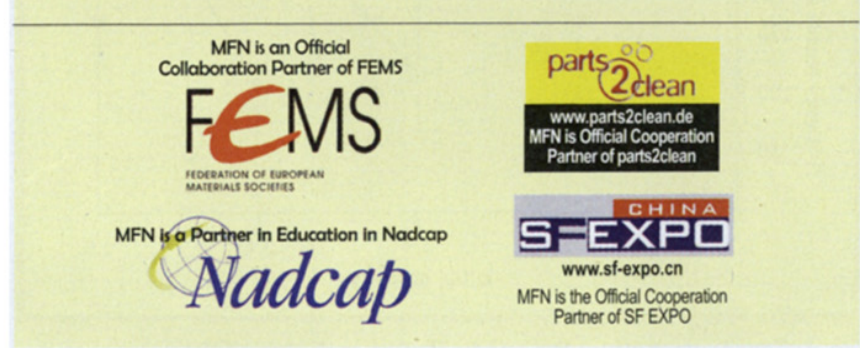

www.metalfinishing.com/advertisers 


\section{TECHNICALLYspeaking}

for high porosity films. The transition between crazing and flaking will be investigated by adding an interfacial crack and observing stress field evolution during thermal cycling.

\section{CONCLUSION AND PROSPECTS}

Initial porosity of films has been proved to largely influence the mechanical behavior of black anodic films. The coloring step results in low tensile residual stresses and decreases the CTE of the film. The film expansion by hydration during sealing results in large compressive stresses. After heating and water desorption, the behavior is the same as a non-sealed film.

Highly porous films have the lower limit tensile stress, affected by coloring and sealing. Combined to tensile stresses induced by the differential thermal dilatations, it results in crazing of highly porous films during sealing.

Aging between $-80^{\circ} \mathrm{C}$ and $+80^{\circ} \mathrm{C}$ has an impact on the adhesion only on samples with an initial porosity of $50 \%$. In this case, the low tensile strength permits the crack propagation during these thermal cycles.

Numerical simulation showed that the presence of cracks is less critical for the interface in highly porous films. Further numerical investigations simulating thermal cycles and including an interfacial crack will be performed to understand the transition between crazing and flaking.

\section{REFERENCES}

[1] Y. Goueffon, L. Arurault, C. Mabru, C. Tonon, P. Guigue, J. Mater. Process. Technol. 209 (11) (2009) 5145.

[2] ESA ECSS-Q-70-03A, Black anodizing of metals with inorganic dyes, 2006. http:// www.ecss.nl.

[3] T. Aerts, Th. Dimogerontakis, I. De Graeve, J. Fransaer, H. Terryn, Surf. Coat. Technol. 201 (2007) 7310.

[4] S.J. Garcia-Vergara, K. El Khazmi, P. Skeldon, G.E.

Thompson, Corros. Sci. 48 (2006) 2937.

[5] P. Skeldon, G.E. Thompson, G.C. Wood, X. Zhou, H.

\section{PLATING EQUIPMENT 타 0 www.hardwoodline.com}

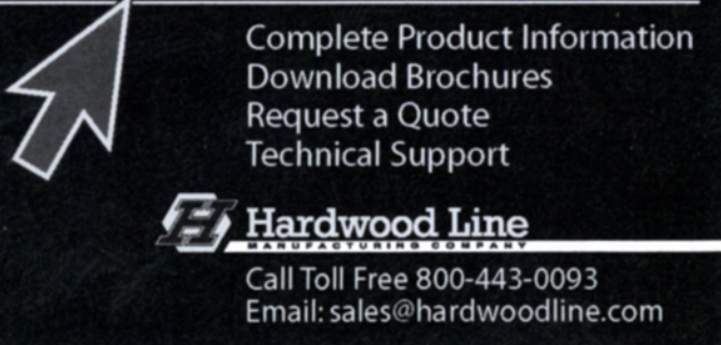

www.metalfinishing.com/advertisers
Habazaki, K. Shimizu, Corros. Sci.

41 (1999) 291.

[6] G. Yan, J.R. White, Polym. Eng. Sci. 39 (1999) 1866.

[7] R.S. Alwitt, J. Xu, R.C. McClung, J. Electrochem. Soc. 140 (5) (1993) 1241.

[8] Y. Goueffon, L. Arurault, S. Fontorbes, C. Mabru, C. Tonon,

P. Guigue, Mater. Chem.Phys., under review.

[9] J.C. Nelson, R.A. Oriani, Corros. Sci. 34 (1993) 307.

[10] L. Arurault, Trans. Inst. Met. Finish. 86 (1) (2008) 51.

[11] R.S. Alwitt, R.C. McClung, S. Jacobs, AAIA Technical Papers (A92-31285 12-23)Washington, D.C., 1992, p. 39.

[12] R.S. Alwitt, R.C. McClung, Plating Surf. Finish. (1993) 48.

[13] P. Skeldon, G.E. Thompson, G.C. Wood, X. Zhou, H.

Habazaki, K. Shimizu, Corros. Sci. 41 (1999) 291.

[14] R.C. Mc Clung, R.S. Alwitt, S. Jacobs, AAIA Technical

Papers (A92-31285 12-23) Washington, D.C., 1992, p. 46.

[15] W.H. Duckworth, J. Am. Ceram. Soc. 36 (1953) 68.

[16] F. Knudsen, J. Am. Ceram. Soc. 42 (1959) 376.

[17] A.K. Sharma, H. Bhojraj, V.K. Kaila, H. Narayanamurthy,

Met. Finish. 95 (12) (1997) 14.

[18] S.J. Bull, Tribol. Int. 30 (7) (1997) 491.

\section{SICTechnologies}

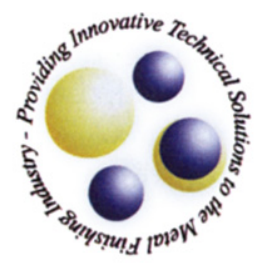

Processes for

ELECTROPOLISHING

Stainless Steel, Aluminum

NON-NITRIC BRIGHT DIPPING

Aluminum castings BD 8605
STRIPPING ANODIC COATING Stripper 5275

ANODIZING

Cleaners, Etch Alkaline \& Acid, Desmut, Anodizing Additives, Seals, Dyes and

Electrolytic Coloring

The Innovators SICTechnologies

(800) 394-9770 • Fax: (404) 351-9887 www.SICTechnologies.com Info@SICTechnologies.com 